\title{
Nilai pH Saliva pada Buruh Perokok di Pelabuhan Bitung
}

\author{
${ }^{1}$ Dwi M. Syukri \\ ${ }^{2}$ Pieter L. Suling \\ ${ }^{1}$ Christy N. Minjelungan
}

\author{
${ }^{1}$ Program Studi Pendidikan Dokter Gigi Fakultas Kedokteran \\ ${ }^{2}$ Bagian Ilmu Penyakit Kulit dan Kelamin Fakultas Kedokteran \\ Universitas Sam Ratulangi \\ Email: Mega_Syukri@yahoo.com
}

\begin{abstract}
Saliva is a complex fluid composed of a mixture of major and minor salivary glands in the oral cavity. The role of saliva is as a protective base between the lining of the oral cavity and toxins. Smoking can affect the physiological function of saliva because smoking destroys molecules in saliva that are useful in protecting the oral cavity, therefore, lack of sensitivity and changes in the sense receptor of taste occur. Saliva acidity setting includes protein, bicarbonate, and phosphate systems. This study was aimed to determine the salivary $\mathrm{pH}$ of the habitual smokers among the laborers at Bitung Port. This was an observational descriptive study using a cross sectional design. Respondents were 30 laborers (males and females) who were habitual smokers, aged 18-45 years old obtained by using purposive sampling technique. The results showed that 13 respondents (43.3\%) had normal salivary $\mathrm{pH}(\mathrm{pH}$ 6.4-7) and 17 respondents $(56.7 \%)$ had basic salivary $\mathrm{pH}(\mathrm{pH}>7)$. The average $\mathrm{pH}$ of all respondents was 7.18. Conclusion: Laborers who were habitual smokers at Bitung port had normal or basic salivary $\mathrm{pH}$.
\end{abstract}

Keywords: salivary $\mathrm{pH}$, laborers, habitual smokers

\begin{abstract}
Abstrak: Saliva merupakan cairan mulut yang kompleks terdiri dari campuran sekresi kelenjar saliva mayor dan minor di dalam rongga mulut dan berperan sebagai pelindung basa antara lapisan mulut dan toksin. Saliva memiliki kemampuan dalam pengaturan derajat keasaman yang berperan penting dalam menjaga nilai $\mathrm{pH}$ di lingkungan mulut seseorang. Merokok dapat memengaruhi fisiologi saliva karena merokok dapat menghancurkan molekul dalam saliva yang berguna dalam melindungi rongga mulut sehingga akan menyebabkan kurangnya sensitivitas dan perubahan reseptor dari indra perasa. Pengaturan keasaman saliva meliputi sistem protein, bikarbonat, dan fosfat. Penelitian ini bertujuan untuk mengetahui $\mathrm{pH}$ saliva pada buruh perokok di pelabuhan Bitung. Jenis penelitian ialah deskriptif observasional dengan menggunakan desain potong lintang. Subjek penelitian ini ialah buruh perokok di pelabuhan Bitung dengan jenis kelamin laki-laki dan perempuan berusia 18-45 tahun. Terdapat 30 responden yang diperoleh dengan mengunakan teknik purposive sampling. Hasil penelitian mendapatkan bahwa 13 responden $(43,3 \%)$ dengan $\mathrm{pH}$ saliva normal $(\mathrm{pH}$ berkisar 6,4-7), dan 17 responden $(56,7 \%)$ dengan $\mathrm{pH}$ basa $(\mathrm{pH}>7)$. Nilai rerata $\mathrm{pH}$ responden sebesar 7,18. Simpulan: Buruh perokok di pelabuhan Bitung memiliki $\mathrm{pH}$ saliva normal atau basa.
\end{abstract}

Kata kunci: pH saliva, buruh, perokok

Saliva adalah cairan kental yang diproduksi oleh kelenjar ludah. Kelenjar-kelenjar ludah tersebut terletak di bawah lidah, daerah otot pipi, dan di daerah dekat langit- langit. Saliva mengandung 99,5\% air ditambah dengan $0,5 \%$ substansi organik dan anorganik. Fraksi organik terutama terdiri dari protein dalam bentuk gliko- 
protein. Fraksi anorganik terdiri dari kalsium, fosfor, sodium, potasium, dan magnesium serta karbondioksida, oksigen dan nitrogen. Enzim saliva yang terutama ialah amilase tetapi dalam keadaan sakit terdapat banyak enzim tambahan yang diproduksi oleh bakteri dan juga dapat ditemukan adanya leukosit. ${ }^{1}$

Saliva mengandung antibodi yaitu enzim peroksidase yang berperan mencegah bakteri dan virus masuk ke dalam tubuh. Saliva juga amat penting untuk melengkapi proses remineralisasi bagi struktur gigi karena air liur mengandung kalsium dan fosfat. Remineralisasi yaitu mengganti mineral-mineral gigi yang hilang akibat erosi (pengikisan) dari asam. Remineralisasi terjadi dengan mendeposit kalsium dan fosfat pada lesi (perlukaan) di bawah email. ${ }^{2}$ Saliva juga penting sebagai bahan penyanggah untuk mengontrol $\mathrm{pH}$ (asam-basa) dalam rongga mulut. Selanjutnya protein yang terdapat dalam air liur, membantu aktivitas antimikroba dengan cara menghambat pertumbuhan bakteri. Protein yang terdapat pada air liur meliputi histatin, laktoferin, peroksidase, dan lisosim.

Pada orang normal saliva memiliki peran sebagai pelindung basa antara lapisan mulut dan toksin. Merokok dapat memberikan dampak fisiologik terhadap saliva karena merokok dapat menghancurkan molekul dalam saliva yang berguna untuk melindungi rongga mulut. Merokok dapat memperpendek kehidupan seseorang sebesar enam menit setiap batang rokok. ${ }^{3}$

Sebuah penelitian menunjukkan bahwa merokok dapat memberikan dampak terhadap $\mathrm{pH}$ saliva. Hal ini dibenarkan oleh Khan et al. ${ }^{4}$ yang. menyatakan bahwa asap rokok menyebar ke seluruh bagian rongga mulut dan reseptor rasa terkena paparan terus-menerus. Jika hal tersebut berlangsung dalam jangka waktu lama maka akan menyebabkan kurangnya sensitivitas dan perubahan reseptor dari indra perasa, dan lama-kelamaan akan menyebabkan supresi refleks saliva. Perubahan respon reseptor rasa dapat berdampak pada perubahan laju aliran saliva. ${ }^{4}$
Saliva memiliki kemampuan dalam pengaturan derajat keasaman, yang berperan penting dalam menjaga nilai $\mathrm{pH}$ di lingkungan mulut seseorang. Pengaturan keasaman saliva meliputi beberapa hal yaitu sistem protein, bikarbonat, dan fosfat. Konsentrasi bikarbonat di dalam saliva dan pH saliva sangat dipengaruhi oleh kadar laju salivasi. Konsentrasi bikarbonat di dalam saliva dan $\mathrm{pH}$ saliva akan meningkat jika kadar laju salivasi meningkat dan begitu juga sebaliknya. Hal tersebut terbukti pada hasil penelitian yang dilakukan oleh Kanwar et al. ${ }^{5}$ yang menunjukkan bahwa ketika kadar laju saliva menurun maka $\mathrm{pH}$ saliva akan menjadi lebih asam.

Meningkatnya sekresi saliva menyebabkan meningkatnya volume dan mengencerkan saliva yang diperlukan untuk proses menelan dan lubrikasi. Peningkatan sekresi saliva juga meningkatkan jumlah dan susunan kandungan saliva, seperti bikarbonat yang dapat meningkatkan $\mathrm{pH}^{6}$ Sebaliknya menurunnya kecepatan sekresi saliva akan menurunkan $\mathrm{pH}$ saliva. ${ }^{7}$ Nilai $\mathrm{pH}$ saliva adalah tingkat keasaman dari cairan saliva. Pada orang normal keadaan fisiologik $\mathrm{pH}$ saliva berkisar antara 6,5-7,4.

Berdasarkan data Riskesdas pada tahun 2013 prevalensi merokok di Indonesia naik dari tahun ke tahun. Rerata batang rokok yang dihisap perhari oleh penduduk usia $\geq 10$ tahun di Indonesia ialah 12,3 batang (setara satu bungkus). Jumlah rerata batang rokok terbanyak yang dihisap ditemukan di Bangka Belitung (18 batang). Proporsi terbanyak perokok aktif setiap hari pada usia 30-34 tahun sebesar 33,4\%. Perokok laki-laki lebih banyak dibandingkan perokok perempuan $(47,5 \%: 1,1 \%)$. Berdasarkan jenis pekerjaan, petani/nelayan/ buruh ialah perokok aktif setiap hari yang mempunyai proporsi terbesar $(44,5 \%)$ dibandingkan kelompok pekerjaan lainnya. Proporsi perokok setiap hari tampak cenderung menurun pada kuintil indeks kepemilikan yang lebih tinggi. Proporsi penduduk usia $\geq 15$ tahun yang merokok dan mengunyah tembakau cenderung meningkat dalam Riskesdas (34,2\%), Riskesdas 2010 (34,7\%) dan Riskesdas 
2013 (36,3\%). Proporsi tertinggi pada tahun 2013 ialah Nusa Tenggara Timur $(55,6 \%){ }^{8}$

Indonesia menduduki peringkat ke-3 dengan jumlah perokok terbesar di dunia setelah China dan India dan tetap menduduki posisi ke-5 setelah China, Amerika Serikat, Rusia, dan Jepang pada tahun 2007 (WHO, 2008). Lebih dari 40,3 juta anak Indonesia berusia 0-14 tahun terpapar dengan asap rokok (menjadi perokok aktif maupun perokok pasif). Hal ini menyebabkan perkembangan pertumbuhan paru anak tersebut menjadi lambat, dan lebih mudah terkena infeksi saluran pernafasan, infeksi telinga dan asma. ${ }^{9}$

Dibandingkan dengan penelitian Global Adults Tobacco Survey (GATS) pada penduduk kelompok usia $\geq 15$ tahun, proporsi perokok laki-laki $67,0 \%$ dan pada Riskesdas 2013 sebesar 64,9\%, sedangkan pada perempuan menurut GATS ialah $2,7 \%$ dan 2,1\% menurut Riskesdas 2013. Proporsi mengunyah tembakau menurut GATS 2011 pada laki-laki 1,5\% dan perempuan $2,7 \%$, sedangkan Riskesdas 2013 menunjukkan proporsi laki-laki 3,9\% dan $4,8 \%$ pada perempuan. ${ }^{9}$ Menurut, data tersebut di atas ternyata prevalensi merokok meningkat setiap tahunnya sehingga hal ini menarik untuk diteliti.

Berdasarkan survei awal yang dilakukan di Pelabuhan Bitung, penulis menemukan cukup banyak buruh yang merokok. Penelitian ini bertujuan untuk mendapatkan pH saliva pada buruh perokok di Pelabuhan Bitung. Pelabuhan Bitung dipilih sebagai lokasi penelitian karena pada lokasi ini belum pernah dilakukan penelitian sejenis serta mudah dijangkau.

\section{METODE PENELITIAN}

Jenis penelitian ini ialah deskriptif observasional dengan desain potong lintang. Penelitian ini dilaksanakan di Pelabuhan Bitung pada bulan Juni 2017 dengan populasi 30 orang. Kriteria inklusi yaitu buruh perokok di pelabuhan Bitung berjenis kelamin laki-laki dan perempuan dengan usia 18-45 tahun.
Data hasil penelitian dihitung secara manual kemudian data dianalisis menggunakan program komputer dan disajikan dalam bentuk tabel dan tulisan.

\section{HASIL PENELITIAN}

Terdapat total 30 responden dari pekerja buruh di pelabuhan Bitung. Tabel 1 memperlihatkan bahwa sebagian besar responden terdistribusi pada usia 28-32 tahun sebanyak 12 responden (40\%), diikuti usia 38-42 tahun sebanyak 5 responden $(16,7 \%)$, usia 23-27 tahun sebanyak 4 responden $(13,3 \%)$, dan usia 18-22 tahun, 33-37 tahun, serta 42-45 tahun masing-masing sebanyak 3 responden (masing-masing sebesar 10\%).

Tabel 1. Karakteristik responden berdasarkan usia

\begin{tabular}{ccc}
\hline $\begin{array}{c}\text { Usia } \\
\text { (tahun) }\end{array}$ & $\begin{array}{c}\text { Frekuensi } \\
(\mathbf{n})\end{array}$ & $\begin{array}{c}\text { Persentase } \\
(\boldsymbol{\%})\end{array}$ \\
\hline $18-22$ & 3 & 10,0 \\
$23-27$ & 4 & 13,3 \\
$28-32$ & 12 & 40,0 \\
$33-37$ & 3 & 10,0 \\
$38-42$ & 5 & 16,7 \\
$43-45$ & 3 & 10,0 \\
Total & 30 & 100 \\
\hline
\end{tabular}

Tabel 2 menunjukkan bahwa berdasarkan distribusi jenis kelamin, responden laki-laki berjumlah 26 orang $(86,7 \%)$ lebih banyak dibandingkan jumlah responden perempuan yang berjumlah 4 orang $(13,3 \%)$.

Tabel 2. Karakteristik responden berdasarkan jenis kelamin

\begin{tabular}{ccc}
\hline $\begin{array}{c}\text { Jenis } \\
\text { kelamin }\end{array}$ & $\begin{array}{c}\text { Frekuensi } \\
(\mathbf{n})\end{array}$ & $\begin{array}{c}\text { Persentase } \\
(\boldsymbol{\%})\end{array}$ \\
\hline Laki-laki & 26 & 86,7 \\
Perempuan & 4 & 13,3 \\
Total & 30 & 100 \\
\hline
\end{tabular}

Tabel 3 menunjukkan bahwa 13 orang responden $(43,3 \%)$ memiliki $\mathrm{pH}$ saliva $6,4-$ $7,0(\mathrm{pH}$ normal) dan sebanyak 17 orang responden $(56,7 \%)$ memiliki $\mathrm{pH}>7,0(\mathrm{pH}$ bersifat basa) dengan rerata $\mathrm{pH}$ seluruh responden sebesar 7,18. 
Tabel 3. Hasil pengukuran $\mathrm{pH}$ saliva

\begin{tabular}{ccc}
\hline Kategori & $\begin{array}{c}\text { Frekuensi } \\
(\mathbf{n})\end{array}$ & $\begin{array}{c}\text { Persentase } \\
(\boldsymbol{\%})\end{array}$ \\
\hline Normal & 13 & 43,3 \\
Asam & - & - \\
Basa & 17 & 56,7 \\
Total & 30 & 100 \\
\hline
\end{tabular}

\section{BAHASAN}

Hasil penelitian ini menunjukkan bahwa 13 orang responden $(43,3 \%)$ ternyata memiliki $\mathrm{pH}$ saliva $6,4-7,0$ yang menunjukkan sifat normal; dan sebanyak 17 orang responden $(56,7 \%)$ memiliki $\mathrm{pH}$ di atas 7,0 yang menunjukkan sifat basa. Hal ini memperlihatkan bahwa derajat keasaman $(\mathrm{pH})$ saliva sangat bervariasi antara responden satu dengan lainnya. Selain itu, nilai $\mathrm{pH}$ saliva pada setiap responden tidak menunjukan penurunan sampai pada tahap nilai $\mathrm{pH}$ kritis.

Perubahan $\mathrm{pH}$ saliva dapat memengaruhi fungsi saliva itu sendiri. Fungsi saliva yang paling berpengaruh yaitu fungsinya dalam memelihara kebersihan rongga mulut dan sebagai antimikroba. ${ }^{10}$ Radikal bebas yang terdapat pada rokok yaitu radikal hidroksil $(\mathrm{OH})$ dapat menyebabkan perubahan struktur dan fungsi molekul dalam saliva. Hal ini disebabkan oleh ion yang terdapat dalam saliva yang berperan dalam proses terbentuknya $\mathrm{OH}$. Hidroksil $(\mathrm{OH})$ dapat merusak tiga jenis senyawa yang penting untuk mempertahankan integritas sel. Salah satunya ialah asam amino penyusun protein yang ada dalam saliva. Asam amino yang paling rawan yaitu sistein. Sistein mengandung gugus sulfhidril (-SH) yang sangat peka terhadap serangan radikal hidroksil. Pembentukan ikatan disulfida (S-S) menimbulkan ikatan intra atau antar molekul sehingga protein (saliva) kehilangan fungsi biologiknya, dan bila protein tersebut berupa enzim maka enzim tersebut akan kehilangan aktifitas katalitiknya. ${ }^{11}$ Pada orang yang merokok pasokan darah ke kelenjar menjadi berkurang karena terjadi penyempitan pembuluh darah yang diakibatkan oleh kurangnya oksigen dalam tubuh karena adanya gas $\mathrm{CO}$ yang berasal dari rokok. ${ }^{12}$
Pada hasil pengukuran $\mathrm{pH}$ saliva minimal pada penelitian ini yaitu 6,4 (Tabel 3). Hal ini menunjukkan bahwa penurunan $\mathrm{pH}$ saliva tidak sampai pada $\mathrm{pH}$ kritis yaitu $<5,5$. Derajat keasaman $\mathrm{pH}$ saliva yang memiliki nilai kritis sekitar 5.5. Pada $\mathrm{pH}$ di bawah nilai kritis dapat menyebabkan enamel gigi mudah larut dan memicu terjadinya demineralisasi sehingga mempermudah terjadinya kerusakan struktur gigi. Selain itu, $\mathrm{pH}$ yang lebih asam dapat meningkatkan proliferasi dari bakteriasi dogenik yang dapat menimbulkan plak gigi dan karies gigi yang pada akhirnya menyebabkan hilangnya struktur gigi. Pengukuran $\mathrm{pH}$ saliva pada penelitian ini langsung dilakukan setelah responden selesai mengeluarkan salivanya. Terjadinya perubahan $\mathrm{pH}$ saliva dipengaruhi oleh beberapa faktor, antara lain diet karbohidrat, irama sirkadian, kapasitas buffer, laju aliran saliva, dan perangsangan sekresi. ${ }^{12}$

Karakteristik responden berdasarkan usia menunjukkan bahwa sebagian besar responden terdistribusi pada rentang usia 28-32 tahun yaitu sebanyak 12 responden (40\%), kemudian diikuti usia 38-42 tahun sebanyak 5 responden (16,7\%), usia 23-27 tahun sebanyak 4 responden $(13,3 \%)$ dan usia 18-22 tahun, 33-37 tahun, serta 42-45 tahun masing-masing sebanyak 3 responden (masing-masing 10\%). Selanjutnya responden diperiksa $\mathrm{pH}$ saliva dengan menggunakan $\mathrm{pH}$ meter. Karakteristik responden berdasarkan jenis kelamin menunjukkan responden laki-laki berjumlah 26 responden $(86,7 \%)$ dan responden perempuan berjumlah 4 responden $(13,3 \%)$.

Keasaman dapat diukur dengan satuan $\mathrm{pH}$. Skala $\mathrm{pH}$ berkisar 0-14, dengan perbandingan terbalik, di mana makin rendah nilai $\mathrm{pH}$ makin banyak asam dalam larutan sebaliknya meningkatnya nilai $\mathrm{pH}$ berarti bertambahnya basa dalam larutan sedangkan pada $\mathrm{pH} 7$ tidak ada keasaman atau kebasaan larutan, dan di sebut netral. Saliva secara normal sedikit asam $\mathrm{pH}$ nya 6,5, dapat berubah sedikit dengan perubahan kecepatan aliran dan perbedaan waktu dalam sehari. ${ }^{12}$

Nilai $\mathrm{pH}$ saliva akan meningkat saat 
merokok namun setelah jangka waktu panjang $\mathrm{pH}$ saliva pada perokok mengalami penurunan jika dibandingkan dengan non perokok. Kelompok perokok memiliki $\mathrm{pH}$ yang lebih rendah dibandingkan kelompok non-perokok akan tetapi $\mathrm{pH}$ pada kedua kelompok tersebut masih dalam kategori normal. Secara umum rokok, baik dari kandungan kimia atau asap rokoknya dapat menyebabkan kerusakan sel dan jaringan pada kelenjar saliva sehingga dapat memengaruhi kelenjar saliva dan saliva itu sendiri. Akibat lanjut ialah terjadi penurunan $\mathrm{pH}$ saliva. Terdapat beberapa hal yang dapat menjadi penyebab, yaitu efek dari paparan rokok saat menghisap rokok dapat mengiritasi mukosa mulut secara langsung. Selain itu, bahan kimia pada rokok dan asap rokok dapat merangsang pelepasan zat kimia dari sel makrofag dan neutrofil aktif seperti IL-1, prostaglandin 2, elastase 3, proteinase, katepasin $\mathrm{G}$ yang dapat merusak sel dan jaringan kelenjar saliva. Hal tersebut dipengaruhi juga oleh lamanya merokok dan jumlah batang perhari yang dapat memperburuk keadaan saliva. $^{13}$

\section{SIMPULAN}

Berdasarkan hasil penelitian dapat disimpulkan bahwa $\mathrm{pH}$ saliva pada buruh perokok di pelabuhan Bitung menunjukkan sifat basa atau normal dengan rerata $\mathrm{pH}$ saliva sebesar 7,18.

\section{SARAN}

Perlu dilakukan penelitian dengan menggunakan rentang waktu pengukuran yang berbeda, sehingga dapat dilihat perubahan $\mathrm{pH}$ saliva. Jumlah sampel untuk penelitian lanjut perlu diperbanyak untuk mendapatkan hasil yang lebih akurat..

\section{DAFTAR PUSTAKA}

1. Mason JD, Eley BM. Buku Ajar Periodonti (2nd ed). Jakarta: EGC, 2013; p. 21-2.

2. Sariningsih E. Gigi Busuk dan Paket Periodontal sebagai Fokus Infeksi.
Jakarta: Elex Media Komputindo Kompas Gramedia, 2014; p. 19-20.

3. Ahmed SSSJ, Raja RR, Raghuwanshi S, Meenakumari S. Studies on the spectral lines of salivary samples taken from smokers and nonsmokers. The Internet Journal of Health. 2010;10(2).

4. Khan GJ, Javed M, Ishaq M. Effect of smoking on salivary flow rate. Gomal Journal of Medical Sciences 2010; 8(2):221.

5. Kanwar A, Sah K, Grover N, Chandra S, Singh RR. Long-term effect of tobacco on resting whole mouth salivary flow rate and $\mathrm{pH}$ : an institutional based comparative study. European J Gen Dent. 2013;2(3):296-9.

6. Rodian M, Satari MH, Rolleta HE. Efek mengunyah permen karet yang mengandung sukrosa, xylitol, probiotik terhadap karakteristik saliva. Dentika. 2011:16(1);44-8.

7. Rahayu FA, Handajani J. Mengkonsumsi minuman beralkohol dapat menurunkan derajat keasaman dan volume saliva. Dentika. 2010;15(1):15-9.

8. Kementerian Kesehatan RI. Riset Kesehatan Dasar 2010. Jakarta: BadanPenelitian dan Pengembangan Kesehatan. [cited 2017 March 15].

9. Riset Kesehatan Dasar (Riskesdas) 2013, Badan Penelitian dan Pengembangan Kesehatan Kementerian Kesehatan RI. [cited 2017 March 20]. Available from: http://www.depkes.go.id/ resources/download/general/Hasil\%2 0Riskesdas\%202013.pdf.

10. Guyton AC, Hall JE. Textbook of Medical Physiology (11th ed). Philadelphia: Elsevier Inc. [cited 2017 April 5].

11. Gondodiputro S. Bahaya tembakau dan bentuk-bentuk tembakau. Bandung: Bagian Ilmu Kesehatan Masyarakat, Fakultas Kedokteran Unversitas Padjadjaran, 2007, p. 11.

12. Amerongen A. Ludah dan Kelenjar Ludah Arti bagi Kesehatan Gigi. Yogyakarta: Gajah Mada University Press, 2010

13. Reibel J. Tobacco and oral Diseases. Update on the evidence with recommendations, 2010 October; p. 22-8 